UDC 165.74

DOI: $10.21847 / 1728-9343.2019 .1(159) .157631$

OSIPTSOV ANDREY,

Mariupol State University (Mariupol, Ukraine)

e-mail: a.osiptsov@mdu.in.ua,ORCID0000-0002-1640-2632

TSYBULKOOLGA,

Mariupol State University (Mariupol, Ukraine)

e-mail: ostsybulco@ukr.net,ORCID0000-0003-1297-5465

\title{
CONCEPTUALITY AND COMMUNICATION AT THE PHILOSOPHICAL TRADITION OF RICHARD RORTY
}

The article deals with the philosophical achievement of Richard Rorty, a bright representative of the English-American tradition of analytic philosophy, in view of the communicative orientation of his key ideas. The author analyzes the attitude of the philosopher towards his contemporary philosophy, especially to the claim of the metaphilosophical theories comprehensive nature. It is shown that the progress of the mankind development can be ensured only in the presence of such an element as a private sphere, where individuals are given the opportunity to freely analyze, study their own aesthetic creations. The scientist developed the ideas of analytical neopragmatism, considering language as a specific human tool, as an instrument of effective human action in the surrounding world. In today's changing world circumstances change with incredible speed, a person has to take into account this, which leads to the inevitable transformation of the language, the presence of multivariate discourses, and the provision of communication between them.

Key words: Richard Rorty; insignificance of philosophy; conceptuality; communication; neopragmatism; understanding; language.

Introduction. In the Western philosophy of the twentieth century, the most striking figures are Husserl, Heidegger, Foucault, Deleuze and Derrida. No less important contribution to the philosophical thought of the last century is made by Richard Rorty, whose philosophical works have given a new impetus to the interpretation and understanding of eternal philosophical problems.

The American philosopher R. Rorty in the scientific literature is considered to be the mediator between the English-American tradition of analytical philosophy and European philosophy. In his works, the scientist presented his view on the subject of philosophy as a science, arguing that philosophy does not study, does not explore, does not describe the real world, but is only a tool, a tool for a pragmatic description and hermeneutic conversation. R. Rorty tries to refute the understanding of the world as a mirror of reality, which was typical for the metaphysical views of classical European philosophy. The scholars described the conversations of the past philosophers on this topic as situational, marked by the historical conjuncture influence, which did not create conditions for the formulation of non-historical, universal truth.

Research Analysis and Research Publications on this issue. R. Rorty's philosophical concept is one of the most popular topics of contemporary philosophical discussions. The works of the philosopher contain an analysis of the critical state of modern philosophy; there are attempts to comprehend the causes of such a state and the ways of overcoming it. Rorty emphasizes the main thing, he speaks of the essence of philosophy in the modern world, emphasizes its meaning and functions.

At the same time, representatives of classical pragma- tism criticize Rorty quite rigorously, accusing him of transforming key ideas of pragmatism and reductionism (Wolf, 1996). Among the works of the researchers of R. Rorty's work, the monograph "Richard Rorty's Neopramatist" is the most significant (Dzhokhadze, 2001). It differs from other works by the systematic presentation of the material and attempts to justify the connections of Rorty's neopragmatism with modern processes in the western philosophical culture.

Purpose. The major aim of this article is to consider the contextual and communicative nature of Richard Rorty's philosophical tradition in the context of insignificance at the post-philosophical culture.

Presenting the Main Material. Main philosophical ideas were developed by R. Rorty and described in such works as "The Meaning of Pragmatism" and "Philosophy after Philosophy: Contingency, Irony and Solidarity" (Rorty, 1996: 145), where he expressed the idea that truth is not revealed, but created in the process of speaking or writing. The only undeniable fact in human life is pain. The task of philosophy is to weaken it, for this in the political sphere, political philosophy there must be a powerful public sector, as many subjects as possible should be involved in the discussion of socio-political issues. R. Rorty emphasizes that progress at the mankind development can be ensured only in the presence of such an element as a private sphere, where individuals are given the opportunity to freely analyze, study their own aesthetic creations.

$\mathrm{R}$. Rorty is considered to be the representative of American pragmatism, who tried to combine the ideas of historicism, post Nietzsche philosophy and neopragmatism in one metaphilosophical concept. The scientist cri- 
ticized the main ideas of traditional metaphysics and epistemology. The researcher referred himself to a circle of supporters of Neoplatonism. First of all, the KantianHegelian, Cartesian distinction between the subject and the object was questioned. In contrast to the representatives of European relativism, who despised naturalism, empiricism, reductionism, representatives of the American pragmatic tradition, tried to overcome the boundaries between philosophy, science and politics. This difference Rorty explained by the fact that Europeans tried to create a phenomenological ontology, a new method of post Nietzsche philosophy. This is primarily about the achievements of early Heidegger and J. P. Sartre.

Instead, the American tradition, according to R. Rorty, did not try to create new methods, but sharply put the antiplatonic question: Do our proclaimed theoretical disputes have any meaning for practice? It is in this context that the scientist evaluates the views of the analytical philosophy representatives, in particular its post-positivist version. According to Rorty, none of the scientists of postpositive analytical philosophy did not consider themselves as a supporters of conceptual analysis. The philosopher believes that their version of post-positivist analytic philosophy is in fact free from any methodological ritualism.

Rorty put forward the project of "destruction" in relation to the previous philosophical tradition, which was characterized by metaphysical, transcendental and fundamental orientations. Classical metaphysics emerged from the metaphor of the mirror in understanding the process of cognition. That knowledge was seen as the apogee of pure reason, which seeks to the best imagine of the world. Rorty believes that such an understanding was canonized by Kant (Wolf, 1996: 201).

With the development and achievements of linguistics of the 20th century, a peculiar "linguistic turn" took place in philosophy. Language began to be seen as a phenomenon, which is a key tool of action and knowledge. Before that, such an instrument was considered an experience. Wrapped up the idea of language as an all-embracing form of human experience, and the person himself began to be understood as a creative, self-actualizing, selfevolving language.

R. Rorty argues that, in contrast to the classical tradition, in the modern pragmatics of the setting of perpetual philosophical problems there is a key difference: from the point of view of the classical tradition, these problems are "found", any thought that is thinking, necessarily confronts them; from a pragmatic point of view - these perpetual philosophical problems are "made", "fictitious", that is, artificial, and not natural (Rorty, 1998: 265).

Pragmatists note that the language of traditional Western philosophy was useful in its time, but ceased to be such.

Characterizing pragmatism, Rorty thinks that the formulation of the problems of the classical tradition is not completely rejected, but it is about the non-acceptance of distinction in binary oppositions "made-found", "imaginaryreal", and replaced by the distinction "more useful-less useful".

The researcher is of the opinion that contemporary purposes require a different language than the language of Greek metaphysics and Christian theology that was necessary and useful for its time. Rorty's key is not a controversy between the classical and pragmatic approaches to a more correct understanding of the universe, but the realization of what we follow for one or another view - in order to prove the truth of the holy letter or for space travel.

Richard Rorty does not regard as a sign of the end or death of loss the modern philosophy of metaphysical issues. It justifies this point of view by the following arguments: philosophy is represented by various concepts and ideas, therefore, it has no internal integrity, there is no problematic core in it, each of the conceptions is essentially a set of useful tools for solving specific problems (Rorty, 1994: 30).

Consequently, philosophy in the sense of Rorty is not a privileged, a priori guarantor of knowledge, it does not prevail in relation to specific sciences, but tends to describe things more than to theorize ones. The scientist connects his philosophy more not with knowledge, but with hope. He focuses on the problems of transformation, reconstruction in the aspect of relative advantage, a possible future, compared with the present, while recognizing the role of chance in social action.

This understanding the meaning, essence and role of philosophy that allowed Rorty to offer his own statement and interpretation of basic philosophical ideas and problems. The main ideas of the scientist are set out in his work "Philosophy and the mirror of nature", where, from the standpoint of the anti-Cartezian and anti-Kantian revolution, he criticizes traditional epistemology and attempts to create his own correct theory of cognition. The philosopher notes the falsity of the Cartesian classical theory of cognition, in the center of the problem of which is the ratio of spiritual and physical, mind and body.

The researcher argues that the consideration of the classical theory of knowledge in the historical and philosophical context is easily revealed by the fact that the main problem in the Antiquity was the question of reason and knowledge, and in the Middle Ages - universals, in the classical Cartesian theory of knowledge - the ratio of opposite substances, spiritual and physical. From the last point of view, the process of knowledge is seen as a mirror image of the external world, the truth of which is attested to by the "inner eye", and consciousness becomes a special reality that can clearly and understandably imagine the outside world. Rorty calls this idea "the invention of consciousness" (Rorty, 1998: 32). This idea gave rise to a variety of concepts - realism, monism, dualism, reductionism, and so on. The American philosopher also calls the operation of such basic concepts of classical epistemology as "intuition", "consciousness", "representation", "spiritual and bodily substance", etc., a kind of "speech game" that continues to this day.

However, such categories as "consciousness", "intuition" do not reflect any reality, because consciousness is not the essence expressed in the language, a whole range of diverse and confused questions, abilities that merge together, which makes intuition an impossible act, but selfawareness (introspection) - the ability that is acquired during the learning process.

In addition, Rorty proposes to abandon the philosophy of "reason", "foundation", "philosophy-as-science" and replace the question of what is consciousness, the question of linguistic behavior, the concept of mental substitute for sociolinguistic.

No less critical, Rorty evaluates Quine and Sellars' views on the problem of "sufficiency" and "necessity", in the process of thinking, he concludes that "the concept of precise representation is an empty compliment" (Rorty, 2000: 47), which is released by the beliefs that allow us do what we want. 
That is why cognition as an "exact representation" is just one of the possibilities that can easily be replaced by a pragmatic concept of cognition, resulting in the elimination of the opposition of action and reflection, the idea of the world and the mastery of the world.

Rorty argues that virtually and mostly among the philosophical beliefs of mankind are not statements and judgments, but insults and metaphors. Therefore, philosophical and any other scientific knowledge does not represent reality, has no soil, can not give true knowledge. Science and philosophy are ways of metaphorically reflecting reality, which change each other and are not proportional.

Immanuel Kant tried to find the basis of knowledge, but F. Nietzsche, the late Wittgenstein and Heidegger substantiated the groundlessness of seeking absolute truth, and Rorty also considered such attempts devoid of meaning. Unlike Kant, Nietzsche and Heidegger viewed philosophy as "teaching, hermeneutics, humanity in the context of culture", and not as a basis for knowledge. Based on this thought, Rorty criticizes the representative theory of truth as the desire for the most adequate reflection of the essence of things, considering the main task of the process of knowledge in describing a particular situation in the context of its usefulness. In the world there is nothing eternal, immutable, rigidly deterministic, absolute, therefore, the desire for universal, the appeal to the absolutes is not the subject of philosophy.

Pragmatism is based on the fact that the search for truth is devoid of meaning, it can not be the purpose of knowledge, Rorty formulates the main task of knowledge as the achievement of "agreement between people in relation to what they should do; reach consensus on those goals to be sought and the means that should be used to achieve these goals" (Rorty, 1979: 267).

If we take this idea as true, then everything that does not lead to the coordination of efforts or behavior is not cognitive efforts, but actually becomes a game of words. That is why any theory should offer a certain plan of action, promote progress, progress in a particular field. The philosopher believes that such an approach overcomes the contrast between precise and social sciences.

Rorty suggests the essence of humanitarian knowledge correlated with literary criticism, and not philosophy. The philosopher distinguishes the notion of "meaning" and "self-determination", first corresponds to the intentions of the author of the text, and the second - reveals the truth, which corresponds to the tasks of philosophy (Dzhokhadze, 2001: 164). This is a communicative tendency in modern philosophy. The researcher believes that the statement acquires meaning not by releasing it from the speaker's consciousness, but due to the context.

If we use concepts such as "objective-subjective", "open-invented", "visibility-reality", then they turn into naked abstractions. Rorty suggests abandoning these dichotomies, refutes the representative theory of knowledge and the correspondence theory of truth in favor of the instrumental. According to the latest knowledge, according to the scientist, is classified not by the criterion of truth or falsity, but from the point of view of usefulness for the specific purposes of the human community. The scientist formulates his goal as follows: "Creating a new and more interesting theory and solidarity with the scientific community through discussion" (Rorty, 1979: 51).

Consequently, the pragmatic philosopher criticizes the encroachment of classical philosophy and science on reliable knowledge. Man needs to cope with the surroun- ding world, so the theory that helps to do it will be true. In other words, the truth is not that which most reflects the world adequately, but those that are more correct to believe.

In the view of Rorty, a person can not find a rational way to find his place in a world that is not rationally organized. Only the assimilation of the necessary human substance is possible. Probable social hope should be based on solidarity, not on objectivity. In fact, Rorty does not only criticizes the philosophical tradition from Antiquity to the Enlightenment, which sought objective truth for its own sake, but categorically denies the binary opposition "thought" and "true knowledge".

The researcher tries to combine the achievements of the "linguistic turn" of positivism from the standpoint of neopragmatism and classical pragmatism; it implies the emergence of a post-philosophical culture that will be directly linked to the completion of the Truth project. The main issue will not be the issue of truth rationality and objectivity, but the question of the personal image of the human community.

Philosophy will act as a mediator for people's mutual understanding, and the truth will be achieved in the context of the assertions we would like to create. Consequently, philosophy can be understood and considered as a way of overcoming conflicts between spheres of culture.

By giving such a characterization of neoclassical philosophy, Rorty develops pragmatic hermeneutics, which subject of study is the dependence of the text interpretations on the needs of the interpreter or community to which the interpreter belongs. The philosopher believes that it is hopeless to share the point of view of Kant, Weber, and even post-structuralists, regarding the impossibility of giving moral meaning to human cognition. He defines spiritual, moral progress as a gradual increase in the ability of people to trust, sympathize with, than to reduce the significance of cruelty.

Rorty analyzes the language, but considering the foregoing, he does not share the views of representatives of the early stage of analytic philosophy, which placed the language into the center of philosophical research. The scientist developed the ideas of analytical neopragmatism, considering language as a specific human tool, as an instrument of effective human action in the surrounding world. In today's changing world circumstances change with incredible speed, a person has to take into account this, which leads to the inevitable transformation of the language, the presence of multivariate discourses, and the provision of communication between them.

The classic tradition tried to answer the question: we invent or open, find out or act. If we consider, according to Rorty, words as tools, beliefs, and not as reflections, they are in fact a habit of behavior, and descriptions of things given to things and originate from our needs. This approach makes the classical question devoid of meaning, as the question which of the descriptions is more true and adequate to things is determined by the degree of interest, need, utility in this description.

Interesting and relevant are R. Rorty's ideas about the problem field "Literature - Philosophy". Today, philosophers and culturologists consider literature as a source of philosophizing, either in the context of the culture of its time (in the days of Antiquity, Socrates and Aristophanes), or as a discussion between generations (HeideggerGölderlin). Researchers complained about the occupation of literature by philosophers and the betrayal of literature by writers capable of formulating philosophical ideas. There is a total enthusiasm for philosophical theories by 
scholars and literary scholars. Modern philosophers emphasize the discovery in the postmodern times of the literary nature of philosophical thought, the danger of its dissolution in postmodern culture.

R. Rorty expressed in his works the idea of the emergence of literary culture as a post-philosophical. From here comes the idea that the characteristic of the scientist position is not only as non-pragmatic, post-analic, but also as a post-philosophical.

Unlike Bloom, who saw literary canon in real literature, categorically denied his social engagement, R. Rorty joined the broader interpretation of the notion of "literature" by Derrida, Lacoue-Labarthe, and Nancy. The philosopher made a deconstruction of this notion, including journalistic reports, television programs, comics, documentaries, ethnographic records and, even, novels and literary criticism. The researcher grants the right to represent literature not only to the writers of the past and modern, but also to C. Darwin, I. Newton, G. Hegel, Heidegger, and others like that.

The widening of boundaries, the notion of "literature" is associated with the destruction of R. Rorty's concept of any boundaries within a culture (Dewey's similar view has already expressed this). The philosopher ironically noted that he replaced the term "literary criticism" with the term "criticism of culture" (Dzhokhadze, 2001: 130), which became a guiding intellectual discipline, since it now plays such a cultural role as it claims to be philosophy, and previously sought to fulfill this role religion, and then science.

It may be noted that $\mathrm{R}$. Rorty's radicalism is sometimes a shocking and provocative one, since the scientist periodically expresses himself more moderately, leaving place for a mentoring philosophy in the post-pseudo-cultural culture. It is about the existence of a "revolutionary scientist", along with a "revolutionary artist". Although literature now performs the task previously performed by philosophy, it does not mean that philosophy passed the baton and disappeared.

R. Rorty considers the mentoring philosophy to be a project for the salvation of philosophy through discovering a more interesting, more recent way of speaking, especially if different cultures and epochs are involved in the dialogue, then the mentoring philosophy becomes hermeneutical activity that promotes mutual understanding. Science denies the Kantian function of philosophy, because it is not the center of culture, but only one of many voices in the conversations of mankind. $R$. Rorty is aware of the absurdity existence of boundaries within the culture, therefore, in the culture of the future there will be a "aesthetic vision" (Dzhokhadze, 2001: 131). The philosopher is subdued from Derrida in relation to the concept of "general text", which, according to Habermas, was based on the deconstruction of philosophical texts.

The central figure in literary culture is called the poet, who is described by the epithet "powerful", because he creates a new dictionary of humanity, he is in avant-garde. According to R. Rorty, the contribution of the poet to social progress is more weighty than the contribution of religion or science and even exceeds the philosophers. Poetry and philosophy were mixed in the works of Novalis, Schlegel, Thich, the first one won the second, the metaphors of discovery lost to the metaphors of self-creation.

$\mathrm{R}$. Rorty contrasts the imagination and the mind, calling the imagination the only source for mankind salvation. Owing to imagination, we are able to sympathize with others, respond to their needs, place themselves in the place of another individual, feel pain, humiliation, joy, etc. It is about replacing Kantian independence with Humic sympathy.

R. Rorty argues as follows: since both the literary work and the philosophical treatise are based on an imaginary world, which may be more influential than real, then literature and philosophy are in the plane of the realization of the imagination. In the article "From Religion through Philosophy to Literature - The Way of Western Intellectuals", the actual summary of the author's understanding of literary culture is summarized. The author observes that representatives of Western culture (intellectuals) sought to create themselves as autonomous individuals, and relying on salvation truth (redemption) (Rorty, 1979: 131). Rorty characterizes ironic this truth as beliefs, which will allow forever to stop thinking about the fact that we can do with ourselves, that everything can be united in a single, always with loyal and natural context.

In fact, the recourse to literature as a savior in the process of creation itself allows you to communicate with extremely diverse human beings in their maximum number, comprehend various vital senses, hopes, goals. Instead of the question "Is something true?" the question "What is new?" is updated. Rorty decrypts this idea in the following way: the search for novelty in the literary culture is connected with the expansion of the boundaries of human imagination, through which they are involved in the literary culture, seeking salvation. Instead of selfknowledge (the idea of Socrates), the Western literary intellectual adheres to the idea of expanding its own self, an instrument of which is the familiarity with a large number of other ways of human existence.

\section{Conclusions}

Consequently, Rorty advocates an opinion on the existence of a post-philosophical culture, in which philosophy, although would not dye, can, however, merge with an extremely widely-acclaimed literature, based on which will be the imagination for the sake of solidarity. Rorty also expressed the idea of the unmanifestation, the insignificance of philosophy, caused by the plurality of its images - philosophy-as-epistemology, philosophy-as-science, philosophy-as-mentoring, philosophy-as-literature, philosophy-as-intellectual game, philosophy-as a system of special practices, etc. However, this rather productive thought did not acquire detailed in the scholarly works of the philosopher.

\section{REFERENCES}

Dzhokhadze, I. D. (2001). Neopragmatizm Richarda Rorti. Trans. from English. Moscow: URSS, 256 p. (In Russian).

Rorty, R. (1979). Philosophy and the Mirror of Nature. Princeton: Princeton University Press, 401 p. (In English).

Rorty, R. (1994). Filosofiya i budushcheye. Trans. from English. Voprosy filosofii. No. 6: 29-34 (In Russian).

Rorty, R. (1996). Sluchaynost, ironiya i solidarnost. Trans. from English. Moscow: Russkoe fenomenologicheskoe obshchestvo, 282 p. (In Russian).

Rorty, R. (1998). Postmodernistskyy burzhuaznyy liberalism. Trans. from English by M. Boychenko. Kyiv: Ukrainskyi filosofskyi fond: 5-13. (In Ukrainian).

Rorty, R. (1998). Priorytet demokratiyi pered filosofiyeyu. Trans. from English by Ya. Popik. Kyiv: Ukrainskyi filosofskyi fond: 14-37. (In Ukrainian).

Rorty, R. (2000). Prahmatyzm i filosofiya. In: K. Baynes (comp.) Pislya filosofiyi: kinets chy transformatsiya? Kyiv: Chetverta khvylia: 24-66. (In Ukrainian) 
Wolf, J. K. (1996). Pragmatizm s metodom ili bez takovogo? Rorti versus D'yui. Trans. from Engl. Logos. № 8: 190-205 (In Russian).

\section{LIST OF REFERENCE LINKS}

Вольф Ж. К. Прагматизм с методом или без такового? Рорти versus Дьюи. Логос. 1996. № 8. С. 190-205.

Джохадзе И. Д. Неопрагматизм Ричарда Рорти. Москва: УРCC, 2001. $256 \mathrm{c}$

Рорти Р. Случайность, ирония и солидарность. Москва: Русское феноменологическое общество, 1996. 282 с.
Рорти Р. Философия и будущее. Вопросы фрилософрии. 1994. № 6. C. 29-34.

Рорті Р. Постмодерністський буржуазний лібералізм / пер. М. Бойченка. К.: Український філософський фонд, 1998. C. 5-13.

Рорті Р. Прагматизм і філософфія. Після філософії: кінець чи трансформація? / упоряд. К. Байнес. К.: Четверта хвиля, 2000. C. 24-66.

Рорті Р. Пріоритет демократії перед філософією / пер. Я. Попіка. К.: Український фрілософсьький фонд, 1998. С. 14-37. Rorty R. Philosophy and the Mirror of Nature. Princeton: Princeton University Press, 1979. 401 p.

Осіпцов Андрій,

Маріупольський державний університет (м. Маріуполь, Украӥна)

e-mail: a.osiptsov@mdu.in.ua,ORCID 0000-0002-1640-2632

Цибулько Ольга,

Маріупольський державний університет (м. Маріуполь, Украӥна)

e-mail: ostsybulco@ukr.net, ORCID0000-0003-1297-5465

\section{КОНТЕКСТУАЛЬНІСТЬ ТА КОМУНІКАТИВНІСТЬУ ФІЛОСОФСЬКІЙ ТРАДИЦІЇ РІЧАРДА РОРТІ}

У статті розглядається філософський здобуток яскравого представника англійсько-американської традиції аналітичної філософії Річарда Рорті 3 огляду на комунікативну спрямованість його ключових ідей. У науковій літературі Р. Рорті прийнято вважати посередником між англійсько-американською традицією аналітичної філософії та філософрією європейською. У своїх роботах науковець виклав свій погляд на предмет філософії як науки, стверджуючи, що філософрія не вивчає, не досліджує, не описує реальний світ, ає лише інструментом, знаряддям прагматичного опису та герменевтичної розмови. Р. Рорті намагається спростувати розуміння світу як дзеркала реальності, що було характерним для метафізичних поглядів класичної європейської філософії. На підставі аналізу робіт "Філософія і дзеркало природи" (1979), "Значення прагматизму" (1982), "Філософрія після фрілософії: випадковість, іронія і солідарність" (1989), "Філософія та майбутнє" (1994) виявлено ставлення філософра до сучасної йому філософії, особливо до претензії на всеохоплюючий характер метафілософських теорій. Акцентовано увагу на його ідеї, що прогрес у розвитку людства можна забезпечити тільки за наявності такого елемента, як приватна сфера, де особистості надано можливість вільно аналізувати, вивчати власні естетичні витвори. Вчений розвинув ідеї аналітичного неопрагматизму, розглядаючи мову як специфічний людський інструмент, як знаряддя ефективної дії людини в оточуючому світі. У сьогоднішній реальності обставини змінюються з неймовірною швидкістю, людині доводиться враховувати це, що й спричиняє невідворотню трансформацію мови, поліваріантність дискурсів, забезпечення комунікації між ними. На підставі цього Рорті обстоює ідею щодо неокресленості, неозначеності філософії, спричиненої множинністю їі іміджів - філософрія-як-епістемологія, філософрія-як-наука, фрілософрія-як-наставництво, філософія-як-література, філософія-як-інтелектуальна гра, філософрія-як-система особливих практик тощо. Проте ця достатньо продуктивна думка не набула деталізації у наукових працях філософа.

Ключові слова: Річард Рорті; неозначеність фрілософії; контекстуальність; комунікативність; неопрагматизм; розуміння; мова.

(C) Osiptsov Andrey, Tsybulko Olga

Надійшла до редакції: 03.12.2018

Прийнята до друку: 08.02.2019 